\title{
Problems and Prospects of Internet Marketing in Russia
}

\section{Elena Gennadievna Gushchina}

Volgograd State Technical University, Russian Federation, 400005, Volgograd, V. I. Lenin Ave., 28

Lidiia Aleksandrovna Sizeneva

Volgograd branch of Academy of Labour and Social Relations, Russian Federation, 400001, Volgograd, Kim st., 6B

Natalia Vasilievna Orlova

Volgograd branch of Moscow Univeristy of Finances and Law MFUA, 400031, Volgograd, Bakhturova st., $25 \mathrm{G}$

\section{Likhovidova Elena Petrovna}

Volgograd Academy of the Ministry of the Interior of the Russian Federation, 400089, Volgograd, Istoricheskaya st., 130

\section{Doi:10.5901/mjss.2015.v6n5p322}

\begin{abstract}
Transformation into information community and total expansion of Internet caused appearance of new sphere of marketing activity "digital marketing" and "Internet-marketing". Forming of new concept of management gives modern instruments, allowing provide successful actions at the market, achieve maximal close contact between different organizations and the target customer at mutual minimization of costs due to use of Internet-media. In the article there are highlighted peculiarities, advantages and restrictions of using Internet-marketing.
\end{abstract}

Keywords: Internet-marketing, concept of management, globalization, information economy, canal of promotion.

\section{Introduction}

At present moment there is ongoing stage of community development - forming of information community. Modern information technologies and telecommunication technologies go to all spheres of life, essentially amending ways to produce products and services, as well as forms of leisure, implementing by human of his or her civil rights, methods and form of upbringing and education. There goes the intensive process of globally forming of "information economy" in total globalization of information-technologies and telecommunication markets appertain of giants of advertizing industry, turning of electronic trade into one of the main kinds of business. (Shakhovskaya et al, 2012)

Transition to global information economy define such achievements in the sphere of information technologies, as expanding of possibilities and influence of global Internet; total availability of modern digital technologies (Wi-Fi, 3GInternet and so on), broad use of databases in different spheres of activity of the community; development of electronic commerce and media of digital marketing.

Dominating and mostly dynamically developing element of the ongoing information community is the global Internet, which, as it should be expected, will keep the status of global information media in the nearest future. It is obvious that number of users these global net would kite.

According to data of analytic company TNS for February of 2013 , at least $76,5 \mathrm{mln}$. of Russians (or $53 \%$ from total population of the country) are online once a month . According to data of public opinion fund, in Russia annually Internet is used by $50 \mathrm{mln}$. of people. Section of active audience, that is using Internet at least once a day is $43 \%$ or $50,1 \mathrm{mln}$. persons. And annual growth of Internet-users, using Internet at least once a month was $11 \%$, and for daily audience it is 13\% (Internet in Russia: dynamics of penetration, 2014)

Internet is the leader as for expansion velocity among ever existing mass media. For the last years Internet was used by $25 \%$ of USA population (compare with telephone that needed 35 years, TV -26 years, radio -22 years, mobile phones - 13 years). By the beginning of 2013 number of Internet-users amounted 1,8 mlrd. persons. The main region where lives 44\% of all Internet users is Asia (922 mln. persons), and the most rapidly growing is the aspect of 
"Internetization" is Africa, where number of users for the last decade grew in 25 times (from 4,5 mln. to $118 \mathrm{mln}$. persons) (Internet: main data and facts, 2014)

According to the Russian national center for studying of public opinion (VTSIOM) pole data, the pole was held in October 2014, Internet is used by 66\% citizens of Russia from 18 years old and older. Everyday $46 \%$ or $53.6 \mathrm{mln}$. of adult Russian people are online. Part of users, which are online some times a week, is 70-80\%. And share of Russians who are from 16 to 29 years old and who use Internet is almost the boundary value - 96\%. Comparing with 2013, increasing of number of users among people of medium are is $23 \%$, among older people is $46 \%$. As it is obvious, growth of Internet audience is mostly due to increasing of share of users who are of medium and older age.

High rate of growth of the online audience provide active distribution of mobile devices. That is in Russia by the end of 2014, audience of Internet users on Smartphone was up to $21 \mathrm{mln}$ persons (17,6\% of population at the age of 16 years and older), and amount of Internet users on tablet PCs increased during one year period more than twice - from 3.5\% in 2013 to 8.4\% at the end of 2014, and became $10 \mathrm{mln}$. of persons (Volkov and Goncharov, 2014)

This statistic data show that Internet is the most rapidly growing mass media in the history of mankind and recently it becomes the social and economic system, and not only to information one. Taking into consideration the factor of growth of the net community the advertizing market of Internet would grow as well, giving the expanded possibilities for promoting any kind of goods and services. Information peculiarities of Internet as well as development of new forms of Internet-advertizing allow getting maximal close contact between different organization and target audience at mutual minimization of expenses. Internet audience is more educated and financially secured comparing with audience of any other media for delivering information. (Gavrilov and Titova, 2012) Most directors and managers use Internet as communication channel and source of information. As it is difficult to predict market environment and transfer to information community, even a small company urgently necessary to be presented in Internet (as a rule it is a web-site).

All this proves the necessity to develop the new concept of marketing and making of optimal algorithms of promoting products and services of the company with the help of Internet.

\section{Methodology}

Addressing to theoretic and methodological matters of Internet-marketing, we can acknowledge the fact, that making of theory and methodology of traditional (classical) marketing is almost completed. And because of that the main directions of development of this concept in the nearest years would be practical and technological. But there is a possibility of new approaches to defining the marketing, specification and expanding of its principles and methods, but this development of methodology of marketing would present the most interest for those who deal with theory, but not practice.

From the point of view of public value we can classify four different objects of marketing, specifying its different aspects. They are: maximizing of consumption, maximizing of satisfying the consumers, maximizing of choosing the consumers, maximizing of quality of life. Achieving of all this objects equally is not possible. For the last decade first of all in economically developed countries there is the tendency for increasing importance of improving of life quality matters. And according to this there was the evolution of concepts of marketing: production, products, selling and concepts of social and ethic, ecological marketing, macromarketing, territorial, megamarketing, global, political marketing and marketing of personality. .

Another approach, suggesting complex use of modern marketing communicative media is «maximarketing» method for increasing to maximum of the sales turnover and income by selective distribution and involving into process of certain potential consumers and clients». This conceptual approach is not something new, and more, it invocate to use modern telecommunication technologies in marketing.

Besides acknowledged concepts of marketing, widely used by the companies to increase effectiveness of promoting goods and services, the important role gets the Internet-marketing. This idea appeared in the early $90^{\text {th }}$ of the last century. Internet-marketing has a big variety of methods for promoting products and services, whose secularity is constant appearance of new instruments and development of the existing ones.

For many years the businessmen used different concepts of management, which should provide successful actions at the market. These concepts appeared in the following chronological order: manufacturer's concept, product concept, sales concept, marketing concept and concept of social and ethic marketing .

Common approach of development methodology of management at implementing the concept of marketing the grater implementation get the principles of synergism, that is providing of common actions for achieving of common object, based on idea, that the whole is something greater than sum of its parts. In marketing this principle means the ability to use of common trade marks, shared participation in holding of NIOKR, making of united systems of goods promotion and logistics, cooperative making of advertizing programs and so on. 
But changes in the environment contributed to fact that companies, for increasing of effectiveness of their business had to change the philosophy of management. As business practice show, for stable getting of profit the companies develop their activity at the direction of marketing concept, which at the present moment is the base for effective management and absolute majority of modern companies try to work at its base.

The idea of marketing concept is to ensure the potential consumer that only your company can satisfy his needs better, then the competitors. Concentration of efforts on solving problems of consumers and evident for the client competence of the company are the main parts of marketing approach. But nevertheless it is not enough. It is necessary that information about promoting of the company itself and their products access customer in the shortest periods and with restricted resources. This problem now is effectively solved by Internet. By using the global net the company may maximally close to the consumer, more accurate and qualitative organize individual service of buyers and work with partners. These new features of interrelation with clients bear the interest to Internet media for the most companies. (Tiago and Tiago, 2012)

All this formed the necessity of forming the new scientific concept in the field of economy and management and effective communicative instrument - Internet-marketing. Now there are lots of definitions of this idea, adding information to each other:

- Internet-marketing is the practice of using all aspects of advertizing in Internet for getting respond from the audience, that includes creative and technical aspects of work in Internet, including design, development, advertizing and marketing (Sharma, 2002);

- Internet-marketing is achieving of marketing tasks via use of digital technologies (Lichtenthal and Eliaz, 2003).

- Internet-marketing is marketing using the new media and opening abilities of communications with the target consumer (Miller, 2010)

In all mentioned above definitions there is traced the common idea of using traditional marketing in Internet media with the emphasis on use of information and communication abilities which Internet provides to traditional marketing.

Comparing with traditional methods of promoting products and services at the market (branding, PR, advertizing, merchandizing, TV-marketing, exhibition and Internet-marketing) according to different parameters (object, typical means, making of object, idea, nature of measures, expenses, effectiveness of using as big companies as small businesses), Internet-marketing is one of the most effective. Besides those methods, as branding, PR and advertizing can be successfully implemented with the help of Internet, which means together with Internet-marketing. (Morozova and Guschina, 2014).

Defining the role of Internet-media in modern conditions, it should be mentioned, that it is not restricted only be communicative functions, but includes the ability of making deals, purchases and transaction of payments, giving it the characteristics of global electronic market. Expanding of global Internet and development of information technologies was the great impact for development of interactive marketing and electronic business. That is why Internet-marketing serves as more massive and effective instrument of promoting products and services not only in big companies, but also small companies to the internal as well as to external markets.

As for problems, solved with the help of Internet - marketing at the external market, that has some sort of specific features, comparing with national market environment. Problems, solved by international Internet-marketing are more complex due to the following:

- necessity of use of every certain outer market and defining feasibility of entering it;

- development of main policy of promoting goods on the selected outer market;

- $\quad$ defining of effective price policy;

- adaption of produced goods to the conditions of target market;

- making of routes for distribution and providing of effective functioning on outer markets;

- overcoming of linguistic barriers.

Additional expenses, connected with solving of these problems are not comparable with analogous expenses on internal market. That is why one of the main problems of using Internet-marketing as method of promoting to the global market is considering of the mentioned above factors.

Thus Internet-marketing is the tool to solve problems of traditional marketing due to use of new communication media, channels for promotion and abilities, presented by Internet-media within the $\mathrm{B}$ global market space. 


\section{Main Instruments, Restrictions and Abilities of Internet-promotion}

\subsection{Structural analyses of promotion media within Internet-media}

You can hardly find a big or small company, that doesn't promote itself in Internet. Advantages of Internet-marketing are not only in ability to cover the target audience. It suggests flexible management of advertising communications. Thus even quite modest advertizing budget guarantees maximal profit. For the ongoing economic situation Internet-marketing becomes main channel for promotion, especially in advertising (Doroshenko, et al, 2013). And that is true for different spheres of business.

Moreover, thought many modern companies try to do Internet-business and implement methods of electronic commerce, but not all of them understand which forms would be the best for them. Nowadays there are companies at the market, which do solely Internet-marketing, suggesting great variety of services for promoting and development of net representative offices of organizations, their optimization, make and implement media-plans, provide and control matters of Internet security.

Promotion of product, as the integral part of complex of marketing is an integral part of the idea of marketing communications. General scheme of marketing communication of a company or complex of promotion is the combination of main marketing communications: advertizing, public relations, personal sale, direct marketing and promoting of sale. Internet-marketing covers searching marketing, banner and context advertizing, e-mail marketing and viral marketing (Guschina et al.,2014)

All these tools are used by the company for making the first and maintaining of the existing demand on all variety of products and services, informing of buyers on changing of parameters of products and services, on place and time of sales; forming of positive opinion on the company itself, its products and services comparing with competitors; making of "information field" round the company.

Certainly, one of the most effective media of promotion is advertizing, about that evidences the level of development the advertizing market globally and in Russia. The following data (table 1) show the structure of global advertizing expenses. In 2010 nearly 72\% of advertizing expenses were on the part of TV and printed media, and Internet took the third place with share 14,1\% (Zenith Optimedia, Advertising Expenditure Forecasts ,013)

Table 1. Structure of global advertizing expenses as for certain segments, $\%$

\begin{tabular}{|c|c|c|c|c|}
\hline No & Segment & 2000 & 2005 & 2010 \\
\hline 1 & Television & 35.9 & 37.1 & 40.3 \\
\hline 2 & Printed media & 46.9 & 42.4 & 31.4 \\
\hline 3 & Internet & 2.2 & 5.4 & 14.1 \\
\hline 4 & Radio & 8.9 & 8.3 & 7.1 \\
\hline 5 & Outer holders & 5.6 & 6.3 & 6.6 \\
\hline 6 & Cinemas & 0.3 & 0.4 & 0.5 \\
\hline
\end{tabular}

The indicated data show that for ten years was important structure change in distribution of advertizing expenses for segments. Rapid development of advertizing in Internet at the same growth of Internet audience caused drawing back of advertising budgets from such classical advertizing media as newspapers and magazines and also radio. That is why greatly decreased share of printed media, a few decreased share of the radio and greatly increased share of Internet. Peculiarities for distribution of advertizing budgets as for branches and segments reflect the specific as well as of the advertizing market itself, as well as more global phenomenon, belonging to this or that country (table 2)

Table 2. Structure of advertizing expenses in different branches of the USA (2009), \%

\begin{tabular}{|c|l|c|c|c|c|c|}
\hline No & Name of Industry & TV & Press & Radio & Internet & Outer advertizing \\
\hline 1 & Retail sale & 39 & 43 & 10 & 6 & 2 \\
\hline 2 & lutomobile sector & 53 & 33 & 6 & 7 & 1 \\
\hline 3 & Finance services & 40 & 24 & 7 & 25 & 3 \\
\hline 4 & Telecommunication sector & 56 & 19 & 6 & 16 & 3 \\
\hline 5 & Food and beverages & 60 & 30 & 4 & 3 & 3 \\
\hline 6 & Media industry & 43 & 42 & 5 & 6 & 3 \\
\hline 7 & Medicine and pharmaceutics & 60 & 30 & 2 & 7 & 0 \\
\hline 8 & Toiletries & 50 & 45 & 1 & 4 & 0 \\
\hline 9 & Other cervices & 45 & 31 & 10 & 9 & 6 \\
\hline
\end{tabular}


Evaluations of Russian market of advertisement in general and as for certain segments are indicated in table 3.

Table 3. Volumes of advertising market in Russia in 2000-2010, mlrd. rubles, including VAT

\begin{tabular}{|l|c|c|c|c|c|c|c|c|c|c|c|}
\hline Years/Segment & 2000 & 2001 & 2002 & 2003 & 2004 & 2005 & 2006 & 2007 & 2008 & 2009 & 2010 \\
\hline TV & 7,9 & 14,9 & 28,8 & 38,1 & 49 & 65,9 & 85,9 & 113,2 & 117,7 & 113,7 & 130,7 \\
\hline Radio & 1,6 & 2,9 & 4,4 & 5,7 & 7,2 & 9,1 & 11,6 & 15,6 & 13,1 & 10,6 & 11,8 \\
\hline Press & 13,1 & 17,9 & 23,8 & 28,8 & 34,6 & 43,3 & 53 & 66 & 63,8 & 42 & 44,8 \\
\hline Outer advertizing & 4,8 & 8 & 12,5 & 16,3 & 20,5 & 25,7 & 32,1 & 40,4 & 45 & 27,3 & 32,3 \\
\hline Internet & 0,0 & 0,2 & 0,4 & 0,7 & 1,6 & 3,0 & 6,4 & 12,7 & 14,9 & 19,1 & 26,7 \\
\hline Others & 0,0 & 0,1 & 0,3 & 0,5 & 0,7 & 1,1 & 1,6 & 2,4 & 2,7 & 2,6 & 3,7 \\
\hline Total & 27,4 & 44 & 70,2 & 90,1 & 113,6 & 148,1 & 190,6 & 250,3 & 257,2 & 215,3 & 250 \\
\hline
\end{tabular}

As it is indicated in the table, dynamic development of native market of advertizing doe not mean proportional development of its segments and placing of some of them was quite unequal: volume of advertizing market in the segment of Internet in 2010 was 130 times greater than in 2001. (Popkova et al, 2013)

\subsection{Other spheres of using Internet and peculiarities of Russian Internet-audience}

As it was mentioned above, Russian Internet-audience has been growing rapidly. As for today less than $30 \%$ of people of our country never used Internet. Number of active users in the national scale doubled for the last three years. Most of Russians use Internet to look for information and to communicate, and about one third of population (34\%) uses it to see the latest news and $20 \%$ to analyze the situation in the country and abroad (picture 1) (Volkov and Goncharov, 2014)

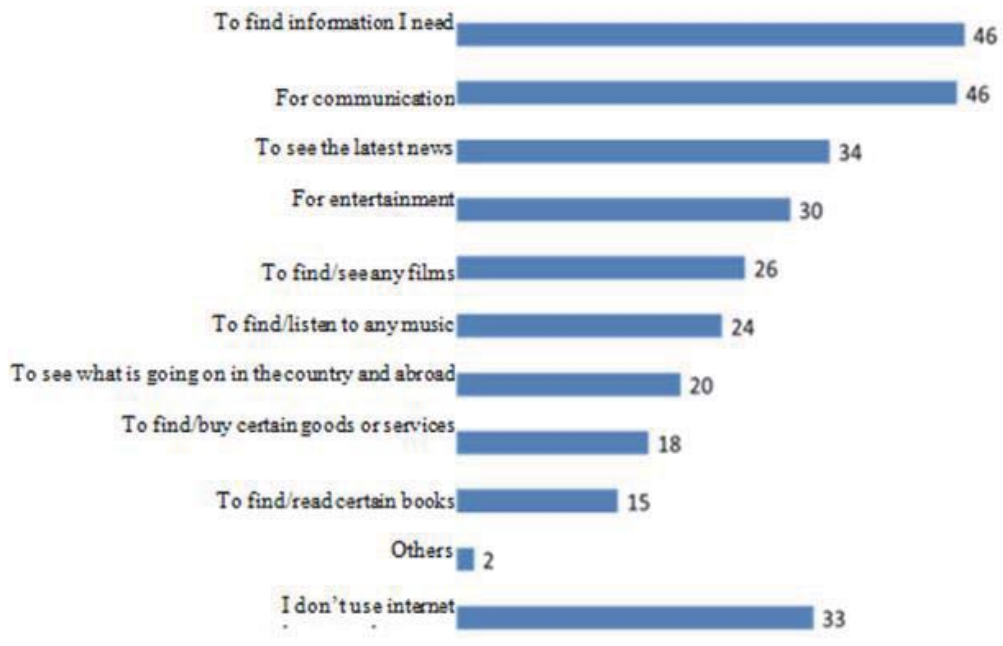

Picture 1. The purposes of using Internet (in \%, Russia, May 2014)

Structure of Russian Internet-audience is quite different. Regular users of Internet are quite younger than population of the country in general (64\% are younger than 40 years; $10 \%$ older than 55 years). Share of people with high education is about $39 \%$, and as for citizens, having income greater than average, that is having the ability to buy foods of long-term use more than 40\%. Among those, who don't use Internet are mostly people of older age, higher education have approximately about $15 \%$, their level of income is not high and lets them to buy mostly food and may be an obstacle for buying a computer, Smartphone and be online. Finally those, who are periodically online, are people older than 40 year old and every fourth has high education, the most part (84\%) don't have a possibility to buy expensive household goods. (Volkov and Goncharov, 2014) Together with increasing of Internet audience in Russia there increases number of social nets users (approximately 50\%). The most popular nets are Vkontakte, Odnoklassniki, Facebook, Twitter, Instagam. 


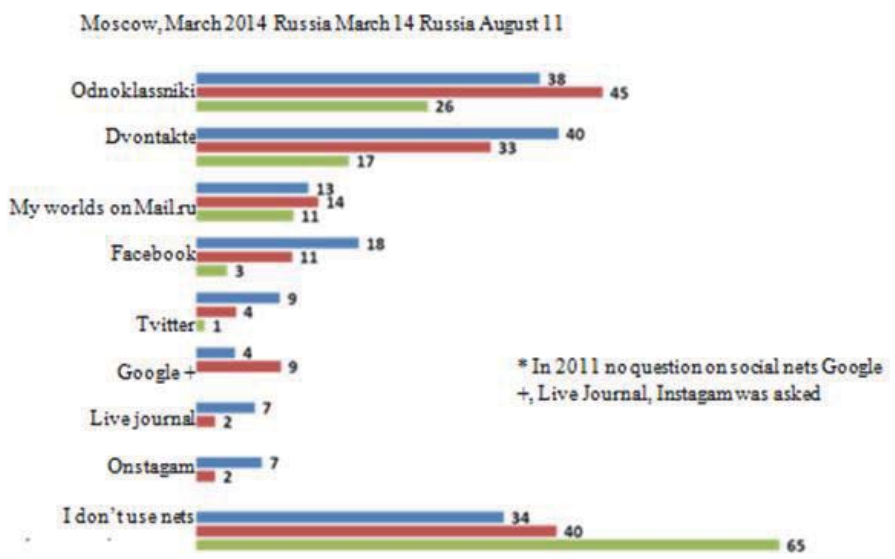

Picture 2. Visiting of different social nets (in \%)

In Russian it is most common the opinion that Internet is the source of free information and is quite an alternative to television, «the TV viewers» are for power and «Internet users» are for opposition (Lipskiy, 2010)

But investigations, made by Levada-Center don't prove these hypotheses [Data of public opinion of those, who live in Moscow of March, 2014 that is a part of investigations «Potential of citizen's participation in the solution of social problems" (Internet in Russia and in world., 2014). Internet as the source of information increases knowing about certain events, but it almost has no impact on political preferences and holding of candidates at elections. Belief to information, got via different channel also has a few meaning. If to compare Russians who trust Net as source of information in general and don't trust television with those, who vice verse trust TV channels and don't trust Internet-resources, then their opinions on actual social and political matters don't differ much. There is no prove of the idea, that people, who learn news for many different sources are more critical in evaluation of high profile incidents despite that they show greater adhesion to democratic ideals.

In the table there are shown the most popular news providers.

Table 4. The most important public and political sites in Moscow (in \%, 2014)

\begin{tabular}{|l|l|l|l|}
\hline Yandex news & 41 & Site of Bi-Bi-Si & 3 \\
\hline Mail.ru news & 21 & Site of Izvastia newspaper & 2 \\
\hline Lenta.Ru & 20 & Fontanka.ru & 2 \\
\hline RBK & 11 & NEWSru.com & 2 \\
\hline Gazeta.Ru & 11 & Russian Journal (russ.ru) & 2 \\
\hline Site RIA News & 9 & Site of Novaya Gazeta & \\
\hline Life News & 8 & Site of Radio svoboda & 2 \\
\hline Kommerstant.ru & 7 & Slon.ru & 2 \\
\hline YTPO.ru & 7 & Snob.ru & 1 \\
\hline Site of Ekho Moskvy & 7 & Sites of foreign mass media on foreign languages (Economist, New York Times and others) & 1 \\
\hline Vedomosti.ru & 4 & Sites of local newspapers, TV channels and Internet-resources & 1 \\
\hline Site of TV channel «Dozht» & 4 & Polit.ru & 1 \\
\hline Grani.ru & 3 & Colta.ru & 1 \\
\hline Sites of federal TV channels & 3 & Casparov. ru & 1 \\
\hline
\end{tabular}

Source: Volkov, D., Goncharov, S. (2014) Russian media environment: television, printed press, Internet Retrieved June 17, 2014, from hhttp://www.levada.ru/17-06-2014/rossiiskii-media-landshaft-televidenie-pressa-internet

So, besides channel of transferring advertizing, Internet is now one of the most valid news information channels, together with Television and as a source of news goes first before newspapers and radio. Thus the abilities of Internet and its 
perspectives as information media have no limits and have not exhaust its potential.

\subsection{Restrictions and potential of development of Internet-marketing}

Despite obvious advantages and values of such channel of promotion as Internet, there are some problems and some restrictions of its development, comparing with traditional canals for promotion. This is first of all about regulating of quality of advertizing services in Internet. Effectively regulate the Internet-advertizing with using of traditional legal forms, regulating the advertizing activity of the companies, can be done not always. That is due to some obvious reasons: legal norms on advertizing are not able to consider technical features of Internet; it is quite difficult to define legislation of what territory should be applicable in certain cases; it is difficult to monitor legalness of performing the advertizing product in Internet and punish for the placing of not quality advertizing .

We can point out two existing points of view as for character of statutory regulation of Internet-advertizing. According to the first one - Russian legislation does not regulate advertizing in Internet. As for the second point of view, according to it Federal Law dated 13.03.2006 No 38-\$3 "On advertizing" regulates different types of Internet-advertizing without considering its specifics. But nevertheless on the basis of this law we can use certain riles and norms of qualified placing of advertisement in Internet.

In Internet it is prohibited to advertize goods, manufacturing and sale of those is prohibited by the law of the Russian Federation. They are drugs and psychotropic medication; explosive materials besides pyrotechnical devices; uncertified and unlicensed goods and services, if they should be obligatory certified; distribution and sale of alcohol and other restricted by the Russian Federation goods; weapons and passion and founded on risk games as well as their organizers. At the condition of adhering of certain rules, it is allowed to advertize alcohol; beer and made on its ground drinks; tobacco goods and goods for smoking; stimulating measures and lotteries; medical services, medicines, and medical equipment, BADs; children's food, finance services and securities, goods for distant selling.

But deepening of crisis tendencies in the development of Russian economy, increasing and aggravating of social problems, spreading of addictive behavior, contributing to growth of criminal cases, alcoholism, drug addiction, violence and bitterness of people, child homelessness, unmotivated violence, number of psychical illnesses and so on causes looking for new forms and methods to work with these negative events of modern worlds and one of them is development of social advertizing, including via Internet net.

Social advertizing is the type of communication, oriented on paying attention to the most actual problems of the society and ways of their solutions, on changing of behavior model of society or forming of moral values of the society. But there is a problem of low effectiveness of social advertizing and one of the reasons is media location. To make the social advertizing campaign effective, it should be not only placed on television, but also on poster panels and in printed press, but also actively use Internet. The next problem of low effectiveness of social advertizing is poor motivation of producers of advertizing, as there is almost no competition in this field. So we can say that those who design and implement social advertizing campaigns just work off state and sponsor's money without any care of effectiveness of the campaigns themselves. That is proved by the fact, that it is quite difficult to find in Internet sites about social problems. If poster panels are easily seen in the street, we can hardly find signs of social sites on the most popular and well-visited Internet-resources.

Consumer must always have the possibility to identify the advertizing. Internet advertizing should not do additional expenses of the user, results of search request must be given according to the given request, otherwise it is intention misrepresentation of the customer. Advertizing with false information is considered defect according to norms of quality.

Due to digital technologies there appeared great number of canals for distribution and getting of marketing information, most of them allow closing places of sale and providing possibility to compare different data about the customers. ). Internet provides marketing expert with excellent media of targeting (getting of target audience not only according to language belonging or place of location, buy for any specialty). Net allows gathering full statistic information in convenient for analyses type, evaluate effectiveness of the selected marketing program and timely amend it, to which actively contribute such popular nowadays social nets, as for example "Facebook", "Twitter" or "VKontakte". (Official site of Association of Communicative Agencies of Russia, 2014)

Specialists, doubting in effectiveness of traditional channels of communication with consumers, greatly intend to use such penetrating and haunting methods, as, for example, RFID-tags and QR-codes. From one side, the picture of target audience allow to make marketing companied more oriented personal, from another - people are anxious to what extend their actions would be tracked and analyzed, how much their personal data would be protected (Karaulova et al, 2013). This may bring to the conflict on matter of confidentiality of information.

Comparing of advantages and disadvantages of Internet-marketing as way to promote products is shown in table. 
Table 5. Advantages and disadvantages of Internet-marketing as the way to promote products

\begin{tabular}{|l|l|}
\hline Advantages & Disadvantages \\
\hline - broad range of audience (not only local, but also national and international market); & $\begin{array}{l}\text { - restrictions in regulations of Internet-resources quality including } \\
\text { - financially reliable and socially active audience; }\end{array}$ \\
- ability of complex description of goods and saving on advertizing and sales & $\begin{array}{l}\text { - counteragents don't trust it as the source of good faith; } \\
\text { - restriction of Internet access for the users of counteragents. } \\
\text { personnel; }\end{array}$ \\
- control of results (strict statistics of marketing campaign effectiveness); & $\begin{array}{l}\text { - there is no guaribantee of confidentiality of information; } \\
\text { - key role goes from producers to users; } \\
\text { - globalization of activity and reducing of transaction expenses; } \\
\text { - personalization of cooperation and transition to marketing "one to one" and reducing } \\
\text { of transformation expenses; } \\
\text { - interactivity }\end{array}$ \\
\hline
\end{tabular}

So, speaking on advantages of Internet-marketing we should underline the effectiveness of Internet-marketing, which is without disadvantages of traditional advertizing and has extra advantages, which make it more effective.

\section{Evaluation of Effectiveness for Promoting of Company's Product with the Use of Internet-Marketing}

\subsection{Peculiarities of different methods of promoting}

To get the competitive advantages, despite information abilities of Internet, we should continuously improve renew products in the conditions of restriction of its lifecycle, watch the market and promptly react ongoing information. Designing and implementation of new products, organization of manufacture and sale should be at the maximum velocity, providing the customers with the requested result. Due to that it is important to evaluate effectiveness of promoting products of the company with the help of Internet-marketing.

There are very few fundamental investigations, touching the problem of development methods of evaluating effectiveness of Internet-promoting. There are few scientific works on using of general methods of evaluating effectiveness. This situation, as a rule, is explained that effectiveness of Internet-promotion depends not only on resource itself, but some controlled and uncontrolled factors, such as: economic situation in the country, season, prices for goods, qualification of personnel and so on. It should be also taken into account, that effect of promotion with the help of Internet can be not immediate and be extended in time, that makes great difficulties to develop actual methods of evaluation the effectiveness of such way of promotion of the company and its products.

Besides evaluating the effectiveness it is necessary to conduct monitoring control and observation of implementation of strategy of promotion to correct it if necessary. Any strategy should be periodically corrected, if not for main directions of development the company, that terms and volumes of its implementation.

Constantly monitoring implementation the strategy is done with the help of indicators, which in the case of deviations are able to provide correcting actions in the necessary direction. Indicators of evaluating effectiveness of promoting of the company products with the help of Internet-marketing should be done on the basis of existing types and methods of Internet-advertizing. Let's see the whole list of indicators while each company should choose for its activity set of necessary indicators individually on the basis of peculiarities and specific characteristic of the goods and activity.

Here is the list of mail types of promotion as for their content.

Media Internet-advertizing (banner advertizing) is placing of graphical and text advertizing on site, which is an advertizing platform. Media advertisement according to many indicators is compared to advertizing materials in printed media. As the banner has got hyperlink and the ability to animate the picture greatly increases the effectiveness of media advertisement.

All contexts Internet-advertizing is distribution of text and graphical advertizing information on context fields. How the advertizing information, which is in advertizing note and context of fields for placing it is defined by algorithm of advertizing service.

Subtype of context advertizing is the search advertizing, in which the indicated above similarity is defined by searching request. Searching Internet-advertizing is placing of text and graphical advertizing notes near with answers for search on sites, or on site of searching systems members, providing the user with function of searching. Showing of specific advertizing notes depends on searching requirements of the user.

Advertizing in social nets is the method, oriented on promotion of company's services or brand via Internet by making of special accounts, pages or groups of companies including in social nets, the most popular net in Russia is Vkontakte. 
Geocontext advertizing is a rule advertizing in mobile phones considering the location of the user. Advertizing in this services, as maps@mail.ru, Yandex.maps, Google maps are also classified as location-based advertising and belongs to methods of promotion or Internet-advertizing. Advertizing information is shown to the user while he sees part of the map considering the context requirement. For example, you can see all beauty shops in certain district of the city.

Viral advertizing is the type of advertizing notes, distributed by visitors of portals and big resources due to independent forming of context, which is able to attract visitors on the site of advertiser due to creative, bright, unusual thought or with the help of trusted or natural notice. As a rule starting point, appeal is flash-attachments, interesting videos and so on.

Placing of products within on-line games (product placement) is uniting of advertizing brand or product within game is one of the newest and rapidly growing spheres of Internet-promotion market. Many brands ensured in perspective and performance of such type of communications with potential customers, taking into account rapid development of audience of the multi users online games and deeper contact with brand, involved in game process. Example of such family of games can be as simple «casual» games, RPG, as well as big multi users strategies. As a fact, for successful promotion within the games are specially good business-simulators, multi-users economic online games, where services, goods and brands themselves become main elements of game process, thus is the highest loyalty of visitors to the advertized brands and very deep contact with every player.

Other types of advertizing in Internet, as a rule, mix the specifications of search and media advertizing notes.

Advertizing with use of e-mail has got certain advantages of use for delivering of information notes:

- almost all Internet users have got e-mail addresses;

- e-mail is so called push-technology of communication;

- $\quad$ it allows to address with use of human properties;

- interesting according to consumer's opinion notice he can distribute among his acquaintances and colleges (Karaulova and Sizeneva,2014).

There are a lot of services in Internet according to thematic postings. Those, who get these postings, agree to get them, and at any time they can and they have the right to terminate their subscription. There are open postings, closed free and payable. As postings usually are systems of communication for the certain target audience and often have thousands of subscribers, this type of Internet-promotion is effective instrument of marketing. Some organizations at their official sites suggest the users to subscribe for postings, informing about the news of the company and renewing of the site. With the help of such posting the owner of the site reminds the subscribers on his/her business and site re-visiting.

Lots of postings to the subscribers have news specifications and function as Mass media, getting income from distribution of advertizing as well. Advertizing notes in the most popular information services, as a rule, looks line banner advertizing notes in Internet. The only difference is in target audience: interests of the audience, social and demographic parameters can depend on not only subject of request but on data of subscribers file data.

Mass posting of advertizing information via e-mail without agreement with the subscriber is spam. Posting of spam is considered to be violations of rules and ethic code of Internet use. Peculiarities of this type of Internet-promotion are not in anonymous of the poster and not that mass posting is not requested posting. Specific features of spam is that most part of expenses for posting of advertizing hold users and Internet-providers, as the source of mass posting doesn't compensate delivering of notes. That is why we can not classify spam to be advertizing, as the advertizing notes use payable line to provide client with notice, Mass posting is restricted or illegal in many countries.

Individual letters or posting of personal letters via e-mail is the instrument of direct-marketing, requiring personalization of notes and time. First addresses should be prepared. The letter is delivered to certain representatives of audience, in whose attention the poster is interested in mostly.

Searching optimization (SEO) gives up to half of visitors for many types of sites and sometimes more. The main condition of getting high values of the schedule is hyperlink in the first lines of giving the results of search for the most popular key phrases. If to take into account that results of search are usually sorted for the maximal match with input request, the optimizer should increase the relevant features of web-pages code to the most popular searching requirements.

Pop-up windows and spy software are the advertizing close to spam which uses the consumer resources for posting it. But this method is not as cheap as spam. And besides it the spy software in many cases is considered harmful program and virus.

Watching of advertizing notes for money or subscription for advertizing notes is the way that didn't show great results comparing with others and in these days it is rarely used.

Electronic announcement board is the site that looks like ordinary advertizing newspapers and announcement boards but qualifiedly differs by frequency of updating of the content and global access. 
Participation in ratings is the way to bring to one sites most part of clients and income and for another - little part. Besides that we often have to pay money for them and there are no honest methods to increase in the rating. That is why this method has nothing to do with standard economic scheme «money-advertizing-visitors-money», which is why it can be conventionally classified as methods of Internet promotion.

\subsection{Indicators of effectiveness of promoting with the help of Internet-marketing methods}

Further we are going to investing methods of promoting from the point of view of their effectiveness. First of all let's evaluate designing and promoting of web -site. Evaluation of effectiveness is deemed to be final stage of work for the development of resource, at objective analyses of the done work. There are a lot of methods and parameter with the help of which there is hold analyses of effectiveness of promotion but there is suggested to classify the following criteria:

- number of orders, got by the company via site,

- detailed analyses of target audience of the recourse,

- recording of website traffic,

- position of the source in the searching system,

- data on registration of site in all possible theme catalogs, business cards,

- report on done work.

Number of orders that company gets via site is the indicator that can be traced in case there is stipulated feedback at the web-site: question to manger, phone call, and orders, made on site and so on. Visiting rate of potential clients is calculated on the basis of requests via that forms. To increase e the target audience for different groups: place where they live, age, sex and so on. Aggregated analyses of quantities and qualitative indexes with highlight «pluses» and «minuses» of web-resource, will allow defining if the suggested goods and services are demanded. From these calculations directly depends evaluation of effectiveness of optimization of site.

The detailed analyses of target audience of the resource stipulate investigation of all request according to which the users go to the resource. Moreover, to the target audience covers those clients hat go to site via different theme catalogues.

Website traffic recordings are the important index. An analysis of effectiveness of work of the theme site is not possible without website traffic recordings. Evaluation of website traffic is done according to the data of visiting the resource according to time periods (months, days, and hours) and locations (cities, regions, countries). Besides that it is very important to record «old» and «new» visitors, these records help to define amount of potential visitors, which return to the resource or visit it for the first time.

Position of the resource in the searching system is also quite an important index. The promoted site must be in Tops of searching systems. Being at the $2^{\text {nd }}-3^{\text {rd }}$ pages of results of outputs for the popular requests is deemed to be more profitable, than at 1 of the medium and less popular, that is explained by the specific features of search.

Data on registration of site in all possible theme catalogues, business-cards are as well important for evaluation of resource effectiveness. As for important place among indexes of effectiveness of optimization of site registration in catalogues takes its proper place. Of course in the case if the object is quality of locations but not their amount. The customer is provided with separate report on work, connected with entrance of web-resource to the theme catalogues.

The final report is necessary for summarizing the results. Evaluation of effectiveness of promoting the site as well as detailed list of done job as a rule is indicated in final month report.

Indexes of evaluation of effectiveness of promoting products of the company using Internet-marketing media are indicated in table.

Evaluation of effectiveness of advertizing policy in Internet in general helps us to define correctness of the selected direction of the advertizing policy as well as feasibility of the expenses on implementation of strategy of promotion. For that purpose expenses on Internet-promotion are compared with aggregated result. Besides that, results on promotion in Internet are compared with the results, got from investments to traditional methods of promotion. But there can be difficulties due to differences in methods of calculation of results in traditional forms and in Internet-promotion. 
Table 6. Indexes of evaluation of effectiveness of promotion products of a company with the help of Internet-marketing media

\begin{tabular}{|l|l|}
\hline Types and methods of Internet advertising notes & Indexes of evaluation effectiveness \\
\hline $\begin{array}{l}\text { Context, searching and media Internet- } \\
\text { advertizing }\end{array}$ & $\begin{array}{l}\text { Amount of shows, amount of uncial shows, crossing of auditoria, price of placing } \\
\text { the advertizing note, frequency of showsa; CPM1; CPUl2; amount of clicks, } \\
\text { amount of uncial clicks; CTR3; frequency of clicks; CPC4; CPUC }\end{array}$ \\
\hline Advertizing in social nets & \\
\hline Geocontext advertizing notes & $\begin{array}{l}\text { Services (maps@mail.ru, yandex maps, Google Maps) with advertizing notes - } \\
\text { amount of services }\end{array}$ \\
\hline Viral advertizing & Locations of viral advertizing and their amount \\
\hline Product placement in online games & The advertised goods (services) in games; game process -amount per game \\
\hline $\begin{array}{l}\text { Advertizing per e-mail, individual e-mail letters, } \\
\text { spam }\end{array}$ & $\begin{array}{l}\text { Clients (posting database) - amount of e-mails, e-mails delivered to addressee - } \\
\text { amount of e-mail addresses; answer on e-mail - amount of e-mail addresses; ; }\end{array}$ \\
\hline Placing of advertizing notes in news postings & $\begin{array}{l}\text { Frequency of posting } \\
\text { Number of advertizing notes }\end{array}$ \\
\hline Searching optimization (SEO) & $\begin{array}{l}\text { Potential clients are in search - amount of requests; amount of people that saw } \\
\text { the site as the result of searching; amount of clicks, amount of uncial clicks. }\end{array}$ \\
\hline Pop-up windows and spy software & $\begin{array}{l}\text { Cost of advertizing company; amount of windows and programs, amount of } \\
\text { clicks, amount of uncial clicks. }\end{array}$ \\
\hline $\begin{array}{l}\text { Watching the payable advertizing notes or } \\
\text { subscribing for advertizing. }\end{array}$ & Cost of advertizing campaign; amount of watching \\
\hline Electronic message board & Amount of electronic messages; price of placement the advertisement \\
\hline Taking part in ratings & Position in rating; amount of clicks, amount of uncial clicks \\
\hline Site & $\begin{array}{l}\text { Meter of statistics - presence, orders, got via internet site - amount. Transitions } \\
\text { to site - amount; Searching systems (Yandex, Rambler, Google) - position in } \\
\text { rating; profile catalogues, business-cards - amount of hyperlinks. }\end{array}$ \\
\hline
\end{tabular}

It should be noted that certain periodical of holding such evaluation using the most appropriate for this resource indexes is important. Successful implementation of strategy of promotion of the company's products with the help of Internet as for making of effective web-site of the company can be at implementation of one important condition: index of re-visiting of site of its target audience is quite high. Implementation of these conditions depends on quality solutions of the following matters: respective information content of the site and its periodical updating; presence of instruments for work with audience; feedback with its visitors.

\section{Conclusion}

It is obvious that modern information media actively hold the technological preparation of production, designing, help to reduce time period, cost and develop the more qualified and competitive product. Within the conditions of economic crisis Russian business structures redistributed the advertizing budgets among segments, preferring the less costing, but more effective, and due to this Internet got more stable position. Thus we can speak about promotion of an organization in Internet as about independent element of marketing of an organization.

Movement to the direction of new channels of promoting, first of all, Internet is the objective reality and result of deep structural changes of the public development. High technologies make the great impact on economy, politics, and development of public institutes. We can tell it for sure, that most canals of distributing information will become digital soon, and the velocity of distributing content, made by companies and by users will greatly increase, media for getting it will unify. Thus for the last several years Internet became the most rapidly growing information media in the history of mankind, that allows to speak not only about perspectives, but about presence of qualifiedly new information and communicative reality in the new concept of marketing (Kortunov and Fedulin, 2013)

Internet marketing has the whole set of tools of classical marketing, and it allows to make it more simple and make

\footnotetext{
1 Index CPM (cost per thousand, M (millesimus) - Latin number for thousand) - cost of thousand shows.

2 Index CPUI (cost per thousand unique impressions) - cost of thousand of uncial shows.

3 Index CTR (click through ratio) - percentage ratio of amount of clicks to amount of shows.

${ }^{4}$ Index CPC (cost per click) - average cost of click.

${ }^{5}$ Index CPUC (cost per unique click) - average cost of uncial click.
} 
it more popular for the most users. Due to Internet, the process of cooperation of all subjects of the market became more open, effective and inter profitable Thus appearance of global Internet expanded the abilities of a company.

The main ideas of Internet-marketing are the same objects and subjects that the traditional marketing has: they are meeting the requirements of users, achieving advantages before competitors, penetrating the market or its segment, providing stable and continuous growth of products sale. Internet-marketing is oriented on attracting of new clients, increasing of information cleanliness of business for getting access to investing resources. The greatest potential is provided by forming of information economy and increasing of quality and velocity of communication between the consumers and the manufacturers.

The more increasing role of Internet-marketing in managing of users and social behavior, distribution of information and impact on mass conscious, requires deeper investigation of this concept as phenomenon influencing base values of the society. Earlier Internet-marketing was deemed to be media for promoting companies or their goods and services, with the help of which it was influence on potential customer up to manipulating his conscious and sub-conscious. But today it becomes obvious, that advertizing can be not only media of marketing communications of companies and organizations, effective form of informing of potential consumers about the goods (service), but also act as certain fundamental value, that performs the most important regulative function for the society.

Due to that fact as possible perspective directions of investigation can become use of Internet as source of social advertizing. Today mostly TV, and less advertizing panels and printed mass media are investigated as holders of social advertizing, and Internet is the least used source for distribution of social advertizing. Actuality of these investigations is defined that at present moment much attention is paid to matters increasing quality of people's lives, solving of severe problems of mankind that increases the value of social advertizing and makes the objects of its future development including with the help of Internet.

\section{References}

Doroshenko, E.I., E.G. Guschina, Zh. A. Chesnokova, 2013. Improvement of Marketing Technologies for Russian Advertising Market Research. World Applied Sciences Journal, 24(9), 1206-1210.

Gavrilov, A.Yu., Titova, T.V. (2012) Management and self-management in the educational activity. Vestnik of tourism and services high schools association 2, 64-71.

Guschina, E.G., Morozova, I.A. and Vitaljeva, E.M. (2014). The Role of the Concept of Advertising in Interaction Between the Market for Education Services and the Sphere of Business. World Applied Sciences Journal, 31(11), 1979-1982. DOI: 10.5829/idosi. wasj.2014.31.11.1705.

Internet in Russia and in world. Internet users in Russia (2014) Retrieved June 28, 2014, from http://www.bizhit.ru/index/users_count/O151.

Internet in Russia: dynamics of penetration: winter 2013/2014 (2014) Retrieved July 23, 2014, from www.runet.fom.ru

Internet: main data and facts. Internet globally and in Russia (2014). Retrieved July 27, 2014, from http://www.bizhit.ru/index/users_ count/0-151

Karaulova, N. M., Sizeneva, L. A. (2014). Elementary Unit of Mechanism of Interests Implementation of Economic Intercourse Subjects. World Applied Sciences Journal, 30 (10), 1380-1383. DOI: 10.5829/idosi.wasj.2014.30.10.14177.

Karaulova, N.M., Sizeneva, L.A., Orlova, N.V., Lubetskiy, M.S. and Chernykh, A.V. (2013). System Analysis and Synthesis of the Concept «Economic Interests' Protection». World Applied Sciences Journal, 27 (Education, Law, Economics, Language and Communication). DOI: www.idosi.org/wasj/wasj27\%28elelc\%2913/68a.pdf

Kortunov, V. and A. Fedulin, A. (2013). A critical analysis of the impact of elecommunications on the worldview of Russian society. Middle East Journal of Scientific Research, 15(10), 1389-1395. DOI: 10.5829/idosi.mejs. 2013.15.10.11614.

Lichtenthal, J.D., Eliaz, Sh. (2003). Internet integration in business marketing tactics. Industrial Marketing Management, 32(1), 3-13.

Lipskiy, A. (2010) «Party of Internet» attacks the «Party of television» Novaya Gazeta, 133 http://www.novayagazeta.ru/politics/ 659.html

Miller, R.J. (2010). Internet Marketing 101. Facial Plastic Surgery Clinics of North America, 18 (4), 509-516

Morozova, I.A., Guschina, E.G. (2014) The Role of the Concept of Advertising in Interaction Between the Market for Education Services and the Sphere of Business World Applied Sciences Journal. 31(11), 1979-1982.

Official site of Association of Communicative Agencies of Russia Date (2014) Retrieved June 23, 2014, from www.akarussia.ru

Popkova, E.G., Morkovina, S.S.,Patsyuk, E.V.,Panyavina, E.A., Popov, E.V., (2013) Marketing strategy of overcoming of lag in development of economic systems. World Applied Sciences Journal 26 (5), 591-595.

Shakhovskaya, L.S., Akimova O.E., Arakelova I.V. (2012) Globalization of economic relations in modern global economy, Volgograd: VolgGTU

Sharma, A. (2002). Trends in Internet-based business-to-business marketing. Industrial Marketing Management, 31(2), 77-84

Tiago, M.T., Tiago, F. 2012. Revisiting the Impact of Integrated Internet Marketing on Firms' Online Performance. European Evidences. Procedia Technology, 5, 418-426. 
Volkov, D., Goncharov, S. (2014) Russian media environment: television, printed press, Internet Retrieved June 17, 2014, from hhttp://www.levada.ru/17-06-2014/rossiiskii-media-landshaft-televidenie-pressa-internet

Zenith Optimedia, Advertising Expenditure Forecasts (2013) Retrieved September 21, 2013 from www.zenithoptimedia.com. 